Original Research Paper

\title{
Study of Ethno Cosmetics Natural Care of Batujai Village Community, West Praya, Central Lombok
}

\author{
Nurul Istiqomah ${ }^{1 *}$, Nisa Isneni Hanifa ${ }^{1}$, Kurniasih Sukenti ${ }^{2}$ \\ ${ }^{1}$ Program Studi Farmasi, Fakultas Kedokteran, Universitas Mataram, Indonesia; \\ ${ }^{2}$ Program Studi Biologi, Fakultas MIPA, Universitas Mataram, Indonesia;
}

\author{
Article History \\ Received : December 30 ${ }^{\text {th }}, 2020$ \\ Revised : January $02^{\text {th }}, 2021$ \\ Accepted : January $09^{\text {th }}, 2021$ \\ Published : January $11^{\text {th }}, 2021$
}

*Corresponding Author:

Nurul Istiqomah,

Program Studi Farmasi, Fakultas

Kedokteran, Universitas Mataram

Mataram, Indonesia;

Email: istyFunram@gmail.com

\begin{abstract}
Cosmetics are a major need for women everyday life, which can be seen from the increasing income of the cosmetics industry for up to $12 \%$ in 2016. Natural ingredients are the alternative to reduce the negative impact of synthetic cosmetics. Knowledge about it is obtained from generation to generation with oral traditions but has several weaknesses. The aims of study to conduct studies related to use of natural ingredients and to find out the value of the use of plants as natural care cosmetics by the people of Batujai village. This research used descriptive methods with qualitative and quantitative approaches, where quantitative data is the result of the calculation of the Index of Cultural Significance (ICS) and Fidelity Level (FL). The results showed that there were 13 natural care cosmetic ingredients consisting of 27 species and 18 families. The potions are children's rapus, rapus golam, rapus mutu, rapus wajah, soap, shampoo, mamak, kejames 1, kejames 2, kejames 3, kejames 4, serbat, and toothpaste. The highest ICS value of 42 was found in the species Oryza sativa L. and the lowest value of 6 was found in the species Amaranthus arenicola, Musa, Cocos nucifera L., Aleurites moluccanus, Aloe vera, Syzygium aromaticum (L.) Merr., Citrus aurantiifolia, Piper retrofractum Vahl, Lannea coromandelica, Jatropha curcas L., Sida rhombifolia L., Ipomoea alba L., Barringtonia racemosa, and Ipomoea sepiaria. FL values range from $25-100 \%$.
\end{abstract}

Keywords: Cosmetics; natural care; potion; ICS; FL.

\section{Pendahuluan}

Kosmetik telah menjadi kebutuhan utama bagi wanita dalam kehidupan sehari-hari. Berdasarkan hasil dari Beauty Market Survey (BMS), pendapatan industri kosmetik Indonesia pada tahun 2016 mencapai Rp 36 triliun, meningkat sekitar $12 \%$ dari tahun sebelumnya. Peningkatan pendapatan industri kosmetik ini didasarkan pada permintaan produk kecantikan dan perawatan yaitu produk perawatan rambut $(37 \%)$, perawatan kulit (32\%) dan dekoratif (10\%) (ITA, 2018). Secara umum, kosmetik terdiri dari 2 jenis yaitu kosmetik sintetis dan kosmetik herbal (Chen, 2009). Kosmetik sintetis dan herbal, masing-masing memiliki kelebihan dan kekurangan, namun kosmetik sintetis memiliki kekurangan yang dapat berdampak buruk bagi kesehatan individu dan lingkungan (Chen, 2009; Parvez et al., 2006).

Pengembangan produk kosmetik herbal merupakan salah satu solusi dalam mengurangi dampak-dampak bahan kosmetik sintesis. Beberapa contoh tumbuhan yang digunakan sebagai kosmetik herbal yaitu minyak kelapa, kunyit dan daun pegagan (Agero dan Vermến, 2004; Wathoni dkk, 2018). Penggunaan kosmetik herbal lebih dipilih karena berasal dari bahan alam, aman, dapat digunakan oleh semua tipe kulit, beragam pilihan, murah, memiliki efek samping rendah, dan tidak mencemari lingkungan, namun bahan-bahan kosmetik herbal ini jarang ditemukan (Joshi dan Pawar, 2015 ; Ramadhania et al., 2018).

Desa Batujai merupakan salah satu desa yang terletak di Kec. Praya Barat Lombok Tengah yang didiami oleh suku Sasak asli Lombok yang masih 
memanfaatkan tumbuhan sebagai pengobatan dan perawatan secara turun temurun (Jannah dan Ridwan, 2013). Berdasarkan informasi dari penghubung, sejak dahulu masyarakat desa Batujai sudah memanfaatkan tumbuh-tumbuhan sebagai ramuan, seperti untuk pengobatan tradisional dan kosmetik perawatan alami. Pengobatan tradisional dari bahan-bahan alam tersebut sudah terbukti berkali-kali dapat menyembuhkan penyakit, sehingga masyarakat semakin percaya dengan pengobatan tradisional.

Selain pengobatan tradisional, masyarakat desa Batujai juga memanfaatkan bahan alam sebagai kosmetik perawatan alami. Sebagai contoh, masyarakat desa Batujai memanfaatkan beberapa bahan alam seperti beras, ketumbar, kayu putih, dan kencur sebagai suatu campuran yang disebut rapus. Khasiat rapus tersebut yaitu untuk membersihkan kulit dari kotoran dan sel kulit mati, menghaluskan, mencerahkan, dan menjaga kelembaban kulit. Hal ini dibuktikan dengan masyarakat desa Batujai yang memiliki kulit yang halus dan bersih. Selain itu, masyarakat desa tersebut juga memiliki rambut yang hitam. Hal ini dikarenakan masyarakat sering menggunakan kelapa atau kemiri yang dibakar kemudian air perasannya dijadikan sebagai minyak rambut yang bermanfaat untuk menghitamkan rambut.

Pengetahuan tentang pemanfaatan bahan alam khususnya tumbuhan sebagai kosmetik perawatan alami tersebut saat ini mulai berkurang, sehingga perlu dilakukan kajian terkait pemanfaatan bahan alam dan pentingnya nilai pemanfaatan tumbuhan sebagai kosmetik perawatan alami oleh masyarakat desa Batujai.

\section{Bahan dan Metode}

\section{Waktu dan Tempat}

Penelitian ini dilakukan pada bulan Agustus Oktober 2020 di desa Batujai, kec. Praya Barat, Lombok Tengah. Bahan yang digunakan dalam penelitian meliputi pedoman wawancara, alat perekam, alat tulis, kamera dan aplikasi GPS, literatur, alat pressing, gunting, alkohol 70\%, kertas mounting, kertas koran, etiket, penggaris, lem, kapas, dan tisu dan lemari herbarium.

\section{Metode}

Metode yang digunakan dalam penelitian yaitu metode kualitatif dan kuantitatif dengan metode sampling yaitu snowball sampling. Pada teknik ini sampel diperoleh melalui proses bergulir dari satu responden ke responden yang lain (Nurdiani, 2014). Penelitian ini dilakukan dalam beberapa tahapan, di antaranya yaitu survei lokasi penelitian, penentuan informan, pengumpulan data tumbuhan kosmetik perawatan alami, pembuatan herbarium dan analisis data.

Analisis data kuantitatif yang digunakan yaitu Index of Cultural Significance (ICS) dan Fidelity Level (FL). Analisis ICS digunakan untuk menentukan nilai-nilai kepentingan setiap jenis tumbuhan yang berguna di masyarakat (Batoro, 2015). Rumus ICS (Turner, 1988) adalah:

$$
\mathrm{ICS}=\sum_{i=1}^{n}(q x i \times e) n i
$$

Analisis Fidelity Level (FL) digunakan untuk mengetahui tingkat kepopuleran atau persentase informan yang menyebutkan penggunaan tanaman untuk khasiat/kategori yang sama '(Ugula, 2012). Rumus FL (Friedman et al., 1986) adalah sebagai berikut:

$$
F L=\frac{N p}{N} \times 100 \%
$$

\section{Hasil dan Pembahasan}

\section{Karakteristik Informan}

Hasil penelitian pemanfaatan tumbuhan sebagai kosmetik perawatan alami diperoleh dari informan yang berlokasi di desa Batujai Kec. Praya Barat Lombok Tengah. Jumlah informan yang berhasil diwawancarai yaitu 9 orang yang tersebar di 3 dusun yaitu dusun Ketangge, Keloke, dan Karang Dalam. Seluruh informan yang diwawancarai merupakan wanita. Hal ini membuktikan bahwa wanita identik dengan konsep kecantikan khususnya dalam hal perawatan tubuh (Na'imah, 2018). Sebagian besar dari mereka memanfaatkan beberapa produk kosmetik ataupun menggunakan resep-resep perawatan kecantikan yang sudah digunakan secara turun temurun oleh nenek moyang mereka untuk mencapai tujuan kecantikan tersebut (Wiharsari, 2019). Selain itu juga, umumnya wanita lebih aktif dalam membudidayakan tumbuhan yang memiliki khasiat di lingkungan sekitar (De Almeida dkk, 2012). Karakteristik informan yang mengetahui 
Istiqomah, N., et al. (2021). Jurnal Biologi Tropis, 21 (1): $32-41$ DOI: http://dx.doi.org/10.29303/jbt.v21i1.2342

penggunaan tumbuhan sebagai kosmetik perawatan alami dapat dilihat pada Tabel 1 .

Tabel 1. Karakteristik informan

\begin{tabular}{lll}
$\begin{array}{l}\text { Bahasa yang } \\
\text { dikuasai }\end{array}$ & Sasak & 9 \\
$\begin{array}{l}\text { Sumber } \\
\text { pengetahuan }\end{array}$ & Orang tua & 9 \\
& Keluarga & 6 \\
& Pendidikan Formal & - \\
& Pendidikan Non-Formal & - \\
& Pengalaman & 5 \\
\hline
\end{tabular}

\begin{tabular}{llc}
\hline \multicolumn{2}{c}{ Karakteristik informan } & Jumlah \\
\hline \multirow{2}{*}{ Jenis kelamin } & Laki & - \\
& Perempuan & 9 \\
\multirow{3}{*}{ Pendidikan (tahun) } & $40-60$ & 2 \\
& $>60$ & 7 \\
& TS (Tidak Sekolah) & 6 \\
& SD/SMP & 2 \\
& SMA & - \\
Pekerjaan & PT (Perguruan Tinggi) & 1 \\
& Buruh tani & 2 \\
& IRT & 3 \\
& Belian & 3 \\
& Lainnya & 1 \\
\hline
\end{tabular}

\section{Aspek Pemanfaatan Kosmetik Perawatan Alami}

Berdasarkan hasil wawancara dengan informan, diperoleh 13 ramuan yang tergolong dalam kategori wajah dan kulit, gigi dan mulut, pasca melahirkan dan bayi, serta rambut. dan terdapat 2 ramuan yang memiliki kategori yang sama. Komponen penyusun ramuan, cara pembuatan, cara penggunaan dan frekuensi penggunaan dapat dilihat pada Tabel 2.

Tabel 2. Komponen ramuan kosmetik perawatan alami

\begin{tabular}{|c|c|c|c|c|c|}
\hline No & $\begin{array}{c}\text { Nama } \\
\text { ramuan }\end{array}$ & $\begin{array}{c}\text { Kategori } \\
\text { Pemanfaatan }\end{array}$ & $\begin{array}{c}\text { Komponen } \\
\text { penyusun }\end{array}$ & Cara pembuatan & Cara aplikasi \\
\hline 1 & Rapus anak & $\begin{array}{l}\text { Wajah dan kulit; } \\
\text { pasca } \\
\text { melahirkan dan } \\
\text { bayi }\end{array}$ & $\begin{array}{l}\text { Pembuatan sediaan } \\
\text { pil dari beras } \\
\text { temulawak, adas, } \\
\text { kencur, ketumbar, } \\
\text { kembang sengeh, } \\
\text { kunyit, kayu manis }\end{array}$ & $\begin{array}{l}\text { - Semua bahan disiapkan dan dicuci bersih } \\
\text { - Beras direndam terlebih dahulu } \\
\text { semalaman } \\
\text { - Semua bahan ditumbuk, ditambahkan } \\
\text { beras dan ditumbuk kembali hingga halus } \\
\text { dan tercampur merata } \\
\text { - Dibuat adonan menjadi bulatan seperti } \\
\text { pil dan dikeringkan }\end{array}$ & $\begin{array}{l}\text { Dilarutkan } \\
\text { beberapa pil dan } \\
\text { dibalurkan pada } \\
\text { tubuh 2-3x sehari }\end{array}$ \\
\hline 2 & Sabun & Wajah dan kulit & $\begin{array}{l}\text { Daun bolah dan } \\
\text { telawek }\end{array}$ & $\begin{array}{l}\text { - Semua bahan disiapkan dan dicuci bersih } \\
\text { - Diambil beberapa lembar daun dan } \\
\text { ditambahkan serbuk telawek (pecahan } \\
\text { genteng) yang sudah ditumbuk } \\
\text { - Campuran tersebut diremas dan } \\
\text { dibalurkan/ digosokkan pada tubuh } \\
\text { - Dibilas hingga bersih }\end{array}$ & $\begin{array}{l}\text { Dibalurkan/ } \\
\text { digosokkan pada } \\
\text { tubuh setiap } \\
\text { mandi }\end{array}$ \\
\hline 3 & Kejames 2 & Rambut & $\begin{array}{l}\text { Air perasan } \\
\text { kelapa/kemiri bakar }\end{array}$ & $\begin{array}{l}\text { - Semua bahan disiapkan dan dicuci bersih } \\
\text { - Kelapa/kemiri dibakar hingga tercium } \\
\text { aroma harum } \\
\text { - Diparut dan diperas sarinya } \\
\text { - Dioleskan merata pada rambut }\end{array}$ & $\begin{array}{l}\text { Dioleskan } \\
2 \mathrm{x} / \text { minggu }\end{array}$ \\
\hline 4 & Mamak & Gigi dan mulut & $\begin{array}{l}\text { Buah pinang, daun } \\
\text { sirih dan kapur }\end{array}$ & $\begin{array}{l}\text { - Semua bahan disiapkan dan dicuci bersih } \\
\text { - Buah pinang dipotong menjadi } \\
\text { seperdelapan bagian dan dikunyah } \\
\text { terlebih dahulu } \\
\text { - Diambil selembar daun sirih } \\
\text { - Ditambahkan kapur di atasnya dan } \\
\text { digulung } \\
\text { - Dikunyah bersama buah pinang hingga } \\
\text { warna berubah menjadi merah }\end{array}$ & $\begin{array}{l}\text { Dikunyah 2- } \\
\text { 3x/hari }\end{array}$ \\
\hline
\end{tabular}


Istiqomah, N., et al. (2021). Jurnal Biologi Tropis, 21 (1): 32 - 41 DOI: http://dx.doi.org/10.29303/jbt.v21i1.2342

\begin{tabular}{|c|c|c|c|c|c|}
\hline 5 & Serbat & $\begin{array}{l}\text { Pasca } \\
\text { melahirkan dan } \\
\text { bayi }\end{array}$ & $\begin{array}{l}\text { Kunyit, jahe, } \\
\text { cengkeh, jeruk } \\
\text { nipis, cabe jawa, } \\
\text { akar bayam pasir, } \\
\text { akar sidaguri, kulit } \\
\text { batang kayu banten, } \\
\text { kulit batang kayu } \\
\text { jarak, gula merah } \\
\text { dan air }\end{array}$ & $\begin{array}{l}\text { - Semua bahan disiapkan dan dicuci bersih } \\
\text { - Kunyit dan jahe ditumbuk kasar } \\
\text { - Dimasukkan air 2-3 gelas ke dalam panci } \\
\text { - Ditambahkan semua bahan dan direbus } \\
\text { hingga mendidih } \\
\text { - Disaring air rebusan } \\
\text { - Diminum }\end{array}$ & $\begin{array}{l}\text { Diminum 1-2x } \\
\text { sehari }\end{array}$ \\
\hline 6 & $\begin{array}{l}\text { Rapus } \\
\text { golam }\end{array}$ & $\begin{array}{l}\text { Wajah dan kulit; } \\
\text { pasca } \\
\text { melahirkan dan } \\
\text { bayi }\end{array}$ & Jahe dan kunyit & $\begin{array}{l}\text { - Semua bahan disiapkan dan dicuci bersih } \\
\text { - Jahe dan kunyit dipotong kecil dan } \\
\text { ditumbuk halus } \\
\text { - Dibalurkan pada tubuh }\end{array}$ & $\begin{array}{l}\text { Dibalurkan 1- } \\
2 \mathrm{x} / \text { hari }\end{array}$ \\
\hline 7 & Sampo & Rambut & Batang padi & $\begin{array}{l}\text { - Bahan-bahan disiapkan dan dicuci bersih } \\
\text { - Joman/sapu ijuk dibakar hingga setengah } \\
\text { bagian } \\
\text { - Direndam dalam air secukupnya } \\
\text { - Air rendaman dioleskan pada rambut }\end{array}$ & $\begin{array}{l}\text { Dioleskan } \\
2 \mathrm{x} / \text { minggu }\end{array}$ \\
\hline 8 & Odol & Gigi dan mulut & Telawek & $\begin{array}{l}\text { - Bahan disiapkan dan dicuci bersih } \\
\text { - Telawek (pecahan genteng) ditumbuk } \\
\text { kasar } \\
\text { - Serbuk telawek digosokkan pada gigi }\end{array}$ & Digosok 1x sehari \\
\hline 9 & Kejames 1 & Rambut & Air batang pisang & $\begin{array}{l}\text { - Batang pisang dipotong/disayat sedikit } \\
\text { - Diambil airnya langsung dari batang dan } \\
\text { ditempatkan pada wadah yang telah } \\
\text { tersedia } \\
\text { - Air batang pisang dioleskan pada rambut }\end{array}$ & $\begin{array}{l}\text { Dioleskan } \\
2 \mathrm{x} / \text { minggu }\end{array}$ \\
\hline 10 & Kejames 3 & Rambut & Daging lidah buaya & $\begin{array}{l}\text { - Diambil lidah buaya } \\
\text { - Dicuci hingga bersih } \\
\text { - Dikupas dan diambil bagian dagingnya } \\
\text { - Dioleskan pada rambut hingga rata }\end{array}$ & $\begin{array}{l}\text { Dioleskan } \\
2 \mathrm{x} / \text { minggu }\end{array}$ \\
\hline 11 & Kejames 4 & Rambut & Daun tandan lilin & $\begin{array}{l}\text { - Semua bahan disiapkan dan dicuci bersih } \\
\text { - Diambil beberapa lembar daun } \\
\text { - Diremas dan diusapkan pada rambut } \\
\text { hingga merata }\end{array}$ & $\begin{array}{l}\text { Dioleskan } \\
2 \mathrm{x} / \text { minggu }\end{array}$ \\
\hline 12 & Rapus mиtu & Wajah dan kulit & $\begin{array}{l}\text { Beras, temulawak, } \\
\text { dan daun turi }\end{array}$ & $\begin{array}{l}\text { - Semua bahan disiapkan dan dicuci bersih } \\
\text { - Beras direndam terlebih dahulu } \\
\text { semalaman } \\
\text { - Temulawak dan daun turi ditumbuk, } \\
\text { ditambahkan beras, ditumbuk kembali } \\
\text { hingga halus dan tercampur rata } \\
\text { - Dibalurkan pada tubuh }\end{array}$ & $\begin{array}{l}\text { Dibalurkan } \\
3 \mathrm{x} / \text { minggu }\end{array}$ \\
\hline 13 & $\begin{array}{l}\text { Rapus } \\
\text { wajah }\end{array}$ & Wajah dan kulit & Beras dan daun turi & $\begin{array}{l}\text { - Semua bahan disiapkan dan dicuci bersih } \\
\text { - Beras direndam terlebih dahulu } \\
\text { semalaman } \\
\text { - Daun turi ditumbuk, ditambahkan beras, } \\
\text { ditumbuk kembali hingga halus dan } \\
\text { tercampur rata } \\
\text { - Dioleskan pada wajah hingga merata }\end{array}$ & $\begin{array}{l}\text { Dioleskan pada } \\
\text { wajah } 3 \mathrm{x} / \mathrm{minggu}\end{array}$ \\
\hline
\end{tabular}

Proses preparasi merupakan proses penyiapan ramuan hingga menjadi bentuk sediaan ramuan kosmetik perawatan alami yang siap untuk digunakan. Berdasarkan hasil wawancara, masing masing ramuan memiliki cara preparasi yang berbeda-beda (Gambar 1). Secara umum cara preparasi yang digunakan meliputi ditumbuk, dibakar, dipotong, diremas, dibuat pil, direbus dan dikunyah. Proses preparasi yang paling banyak digunakan yaitu ditumbuk sebanyak $(30,77 \%)$. 


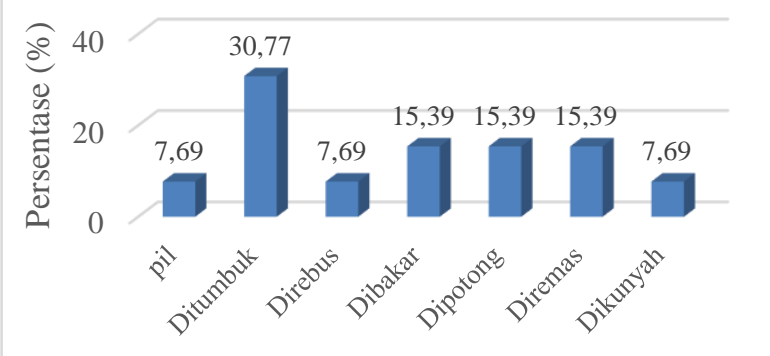

Gambar 1. Proses preparasi tumbuhan kosmetik perawatan alami

Bentuk sediaan ramuan kosmetik perawatan alami masyarakat desa Batujai sangat beragam. Contoh bentuk sediaannya yaitu pil dan jamu (Gambar 2). Salah satu ramuan yang dibuat menjadi sediaan pil adalah rapus anak. Cara penggunaannya yaitu sediaan pil dileburkan terlebih dahulu dengan air dan dibalurkan pada tubuh. Selain itu, contoh sediaan lain yaitu jamu. Ramuan yang biasanya dibuat menjadi sediaan jamu yaitu serbat. Cara penggunaannya yaitu dengan cara diminum. Masyarakat desa Batujai biasanya menggunakan serbat untuk membantu mengembalikan bentuk tubuh pasca melahirkan dan melangsingkan tubuh.

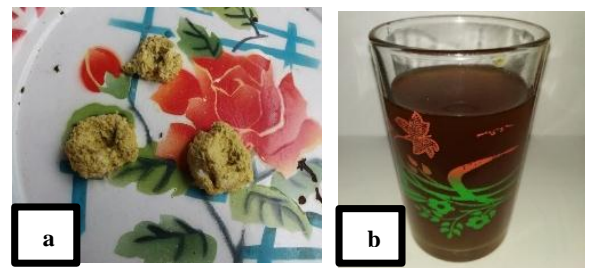

Gambar 2. Bentuk sediaan pil rapus anak (a) dan jamu serbat (b)

\section{Aspek Botani}

Berdasarkan hasil wawancara dengan informan, tumbuhan yang dimanfaatkan sebagai kosmetik perawatan alami sebanyak 27 spesies tumbuhan dengan 18 famili (Tabel 3). Hal ini membuktikan bahwa pemanfaatan tumbuhan sebagai kosmetik perawatan alami oleh masyarakat desa Batujai cukup tinggi. Tumbuhan kosmetik perawatan alami yang digunakan berasal dari famili Zingiberaceae (14,81\%), Aracaceae (11,11\%), Piperaceae, Apiaceae, Euphorbiaceae, Convolvulaceae $(7,41 \%)$, Poaceae, Fabaceae, Lauraceae, Amaranthaceae, Musaceae, Aloaceae, Myrtaceae, Malvaceae, Rutaceae, Anacardiaceae, Lecythidaceae, Caryophyllaceae $(3,7 \%)$. Famili yang paling banyak digunakan berasal dari famili Zingiberaceae dengan jumlah famili terdiri dari 4 spesies. Famili Zingiberaceae diketahui memiliki kandungan minyak atsiri yang berperan sebagai antioksidan, antiinflamasi, dan antimikroba (Julie dan Ernest, 2012). Salah satu tumbuhan yang tergolong famili Zingiberaceae yaitu jahe. Hasil penelitian yang dilakukan oleh Shobana dan Naide (2000) menunjukkan bahwa ekstrak alkohol jahe (Zingiber officinale) mempunyai aktivitas antioksidan yang kuat. Antioksidan dapat berfungsi dalam membantu menangai proses penuaan dengan cara menstabilkan radikal bebas yang berperan dalam photoaging, karsinogenesis dan imunosupresi (Andarina dan Djauhari, 2017).

Tabel 3. Daftar tumbuhan yang dimanfaatkan sebagai kosmetik perawatan alami masyarakat desa Batujai

\begin{tabular}{cllllc}
\hline \multirow{2}{*}{ No } & \multicolumn{1}{c}{ Famili } & \multicolumn{1}{c}{ Nama } & \multicolumn{1}{c}{ Spesies } & $\begin{array}{c}\text { No Kategori } \\
\text { Pemanfaatan }\end{array}$ \\
\cline { 2 - 6 } & Indonesia & Apiaceae & Foeniculum vulgare Mill & Adas & 1,7 \\
\hline 1 & Adas & Arecaceae & Arenga pinnata (Wumb) Merr. & Gule beak (Aren) & 7 \\
2 & Aren & Anacardiaceae & Lannea coromandelica (Houtt.) Merr. & Jaran & 7 \\
3 & Banten & Amaranthaceae & Amaranthus arenicola I.M. Johnst. & Lembain biras & 1,7 \\
4 & Bayam pasir & Sebie gawah & 7 \\
5 & Cabe jawa & Piperaceae & Piper retrofractum Vahl & Jarak & 7 \\
8 & Jarak & Euphorbiaceae & Jatropha curcas L. & Jeruk nipis & 7 \\
9 & Jeruk nipis & Rutaceae & Citrus aurantiifolia (Christm.) Swingle & Kayu manis & 1,7 \\
10 & Kayu manis & Lauraceae & Cinnamomum verum J. Presl & Nyiur & 2 \\
11 & Kelapa & Arecaceae & Cocos nucifera L. & Lekong & 2 \\
12 & Kemiri & Euphorbiaceae & Aleurites moluccanus (L.) Willd. & Ketumbah & 1,7 \\
13 & Ketumbar & Apiaceae & Coriandrum sativum L. & Sekuh & 1,7 \\
14 & Kencur & Zingiberaceae & Kaempferia galanga L. & \\
\hline
\end{tabular}


Istiqomah, N., et al. (2021). Jurnal Biologi Tropis, 21 (1): $32-41$ DOI: http://dx.doi.org/10.29303/jbt.v21i1.2342

\begin{tabular}{|c|c|c|c|c|c|}
\hline 15 & Kunyit & Zingiberaceae & Curcuma longa $\mathrm{L}$. & Kunyik & 1,7 \\
\hline 16 & Lidah buaya & Aloaceae & Aloe vera (L.) Burm.f. & Lidah buaya & 2 \\
\hline 17 & Padi & Poaceae & Oryza sativa $\mathrm{L}$. & Beras (Pari) & 1,7 \\
\hline 18 & Pinang & Arecaceae & Areca catechu L. & Buak & 5 \\
\hline 19 & Pisang & Musaceae & Musa & Kedebong Puntik & 2 \\
\hline 21 & Sirih & Piperceae & Piper betle L. & Likuk & 5 \\
\hline 22 & Turi & Fabaceae & Sesbania grandiflora (L.) Pers & Daun Ketujur & 1 \\
\hline 23 & Temulawak & Zingiberaceae & Curcuma zanthorrhiza Roxb. & Ingguh & 1,7 \\
\hline 24 & Soapwort & Caryophyllaceae & Saponaria officinalis L. bouncingbet & Kembang sengeh & 1,7 \\
\hline 26 & Buah Putat & Lecythidaceae & Barringtonia racemosa (L.) Spreng. & Buak putrat & 1 \\
\hline 27 & - & Convolvulaceae & Ipomoea sepiaria Koenig ex Roxb. & Daun tandan lilin & 2 \\
\hline
\end{tabular}

Tumbuhan yang dimanfaatkan oleh masyarakat desa Batujai diperoleh dari berbagai macam tempat. Terdapat beberapa tumbuhan yang tidak diperoleh langsung pada habitatnya, namun diperoleh dengan cara membeli. Sumber perolehan tumbuhan paling banyak yaitu dengan cara membeli di pasar sebanyak (44,44\%), budidaya (sawah, kebun dan pekarangan) $(25,93 \%)$, dan liar (hutan dan selain sawah dan kebun) $(29,63 \%)$.

Bagian tumbuhan yang biasanya digunakan sebagai kosmetik perawatan alami yaitu daun, buah, biji, rimpang, batang, bunga dan akar (Gambar 3). Bagian tanaman yang paling banyak digunakan oleh masyarakat desa Batujai yaitu daun (25\%). Hal ini dikarenakan bagian daun mudah dalam pengambilannya dan mudah tumbuh kembali (Novianti, 2014). Cara pengolahan bagian daun lebih mudah dibandingkan dengan bagian lain dari tumbuhan karena tekstur dari daun yang lunak (Wahidah, 2013: Irawan et al., 2013). Selain mudah diolah, senyawa kimia yang berkhasiat pada bagian daun juga diketahui lebih banyak dibandingkan bagian lainnya seperti flavonoid, tannin, saponin, fenol dan alkaloid (Simorangkir et al., 2017).

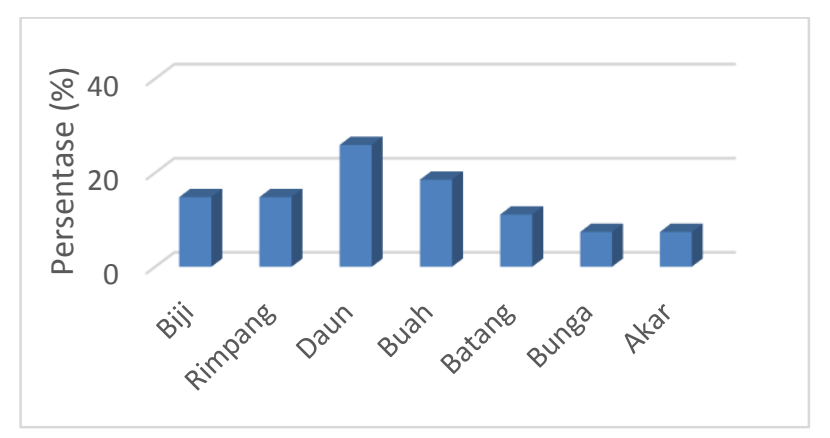

Gambar 3. Bagian/organ tumbuhan
Analisis data tumbuhan dilakukan secara kualitatif dan kuantitatif. Analisis kuantitatif digunakan untuk mendukung data kualitatif tumbuhan. Data tumbuhan dianalisis dengan metode ICS (Index of Cultural Significance) dan FL (Fidelity Level).

\section{a. Index of Cultural Significance (ICS)}

Indeks of Cultural Significance (ICS) merupakan indeks yang bertujuan untuk mengetahui atau mengukur nilai kepentingan setiap jenis tumbuhan yang berguna bagi masyarakat, terkait jenis, kegunaan, intensitas penggunaan dan tingkat kesukaan masyarakat (Batoro, 2015; Eni et al., 2019). Nilai ICS tumbuhan kosmetik perawatan alami diilustrasikan pada Tabel 4 .

Tabel 4 menunjukkan bahwa terdapat 3 spesies dengan nilai ICS tertinggi meliputi Oryza sativa L., Curcuma longa L., dan Zingiber officinale Roscoe dengan masing-masing nilai ICS yaitu 42, 30, 30. Spesies dengan nilai ICS yang tinggi merupakan spesies dengan tingkat kepentingan yang relative tinggi dibandingkan spesies lainnya sebagai tumbuhan kosmetik perawatan alami masyarakat desa Batujai. Berdasarkan hasil wawancara dengan informan, tumbuhan yang memiliki nilai ICS tertinggi dilaporkan memiliki ragam pemanfaatan yang banyak. Semakin tinggi jumlah ragam pemanfaatan suatu tumbuhan, maka semakin tinggi pula nilai skor kualitas, intensitas pemanfaatan, dan tingkat kesukaan masyarakat terhadap suatu tumbuhan pada nilai ICS (Eni et al., 2019).

Sementara itu, spesies dengan nilai ICS terendah terdapat pada spesies Amaranthus arenicola, Musa, Cocos nucifera L., Aleurites moluccanus, Aloe vera, Syzygium aromaticum (L.) Merr., Citrus aurantiifolia, Piper retrofractum Vahl, Lannea coromandelica, Jatropha curcas L., Sida 
rhombifolia L. Ipomoea alba L., Barringtonia racemosa, dan Ipomoea Sepiaria. Nilai ICS yang rendah ini menunjukkan bahwa pemanfaatan tumbuhan tersebut sebagai kosmetik perawatan alami tidak terlalu signifikan. Hal ini disebabkan karena jumlah ragam pemanfaatan yang sedikit, sehingga berpengaruh terhadap nilai skor kualitas, intensitas pemanfaatan, dan tingkat kesukaan masyarakat yang rendah.

Tabel 4. Nilai ICS tumbuhan kosmetik perawatan alami

\begin{tabular}{|c|c|c|c|}
\hline No & Nama Lokal & Nama Spesies & $\begin{array}{l}\text { ICS } \\
\text { total }\end{array}$ \\
\hline 1 & Beras (Pari) & Oryza sativa $\mathrm{L}$. & 42 \\
\hline 2 & Kunyik & Curcuma longa $\mathrm{L}$. & 30 \\
\hline 3 & Jai & $\begin{array}{l}\text { Zingiber officinale } \\
\text { Roscoe }\end{array}$ & 30 \\
\hline 4 & Likuk & Piper betle L. & 18 \\
\hline 5 & Buak & Areca catechu L. & 18 \\
\hline 6 & $\begin{array}{l}\text { Gule beak } \\
\text { (Aren) }\end{array}$ & $\begin{array}{l}\text { Arenga pinnata } \\
\text { (Wurmb) Merr. }\end{array}$ & 18 \\
\hline 7 & Adas & $\begin{array}{l}\text { Foeniculum vulgare } \\
\text { Mill. }\end{array}$ & 12 \\
\hline 8 & Ketumbah & Coriandrum sativum $\mathrm{L}$. & 12 \\
\hline 9 & Sekuh & Kaempferia galanga L. & 12 \\
\hline 10 & Daun ketujur & $\begin{array}{l}\text { Sesbania grandiflora } \\
\text { (L.) Pers }\end{array}$ & 12 \\
\hline 11 & Kayu manis & $\begin{array}{l}\text { Cinnamomum verum } \mathrm{J} . \\
\text { Presl }\end{array}$ & 12 \\
\hline 12 & Ingguh & $\begin{array}{l}\text { Curcuma zanthorrhiza } \\
\text { Roxb. }\end{array}$ & 12 \\
\hline 13 & $\begin{array}{l}\text { Kembang } \\
\text { sengeh }\end{array}$ & $\begin{array}{l}\text { Saponaria officinalis L. } \\
\text { bouncingbet }\end{array}$ & 12 \\
\hline 14 & Daun bolah & Ipomoea alba $\mathrm{L}$. & 6 \\
\hline 15 & Buak putrat & $\begin{array}{l}\text { Barringtonia racemosa } \\
\text { (L.) Spreng }\end{array}$ & 6 \\
\hline 16 & $\begin{array}{l}\text { Daun tandan } \\
\text { lilin }\end{array}$ & $\begin{array}{l}\text { Ipomoea sepiaria } \\
\text { Koenig ex Roxb. }\end{array}$ & 6 \\
\hline 17 & Sangkeguri & Sida rhombifolia L. & 6 \\
\hline 18 & Lembain biras & $\begin{array}{l}\text { Amaranthus arenicola } \\
\text { LM. Johnst. }\end{array}$ & 6 \\
\hline 19 & $\begin{array}{l}\text { Kedebong } \\
\text { puntik }\end{array}$ & Musa & 6 \\
\hline 20 & Nyiur & Cocos nucifera $\mathrm{L}$. & 6 \\
\hline 21 & Lekong & $\begin{array}{l}\text { Aleurites moluccanus } \\
\text { (L.) Willd. }\end{array}$ & 6 \\
\hline 22 & Lidah buaya & Aloe vera (L.) Burm.f. & 6 \\
\hline 23 & Jeruk nipis & $\begin{array}{l}\text { Citrus aurantiifolia } \\
\text { (Christm.) Swingle }\end{array}$ & 6 \\
\hline 24 & Cengkeh & $\begin{array}{l}\text { Syzygium aromaticum } \\
\text { (L.) Merr. \& LMPerry }\end{array}$ & 6 \\
\hline 25 & Sebie gawah & Piper retrofractum Vahl & 6 \\
\hline 26 & Jaran & $\begin{array}{l}\text { Lannea coromandelica } \\
\text { (Houtt.) Merr. }\end{array}$ & 6 \\
\hline 27 & Jarak & Jatropha curcas L. & 6 \\
\hline
\end{tabular}

\section{b. Fidelity Level (FL)}

Parameter ICS dan FL memiliki hubungan yang saling terkait untuk kepentingan suatu spesies. Nilai ICS menunjukkan kepentingan suatu tumbuhan berdasarkan tingkat jumlah ragam pemanfaatan, sedangkan nilai FL menunjukkan tingkat kepentingan suatu tumbuhan berdasarkan kategori pemanfaatan yang lebih spesifik. Jenis-jenis tumbuhan yang memiliki nilai ICS dan FL yang tinggi dapat menjadi dasar pengembangan suatu jenis tumbuhan untuk dilakukan penelitian lebih lanjut terkait kandungan senyawa bioaktifnya untuk pemanfaatan tertentu (Eni et al., 2019).

Fidelity Level (FL) merupakan persentase informan yang menyebutkan penggunaan tanaman tertentu untuk tujuan/khasiat yang sama (Khan et.al., 2014). Menurut Hoffman dan Gallaher (2007), Fidelity Level (FL) merupakan nilai untuk mengukur homogenitas/keseragaman informasi narasumber terhadap penggunaan suatu jenis tumbuhan untuk ragam pemanfaatan tertentu. Nilai FL tumbuhan yang diperoleh berkisar antara 25 sampai $100 \%$. Nilai indeks FL tumbuh kosmetik perawatan alami diilustrasikan pada Tabel 5.

Tabel 5 menunjukkan bahwa nilai FL yang diperoleh merupakan persentase keseragaman informasi dari informan mengenai 27 jenis tumbuhan yang tergolong ke dala 4 kategori sebagai kosmetik perawatan alami masyarakat desa Batujai. Dari hasil penelitian, terdapat 26 spesies yang memiliki nilai FL $100 \%$ untuk satu atau lebih kategori pemanfaatan. Nilai FL 100\% menunjukkan bahwa tumbuhan tersebut merupakan jenis tumbuhan yang paling disukai dan paling sering digunakan masyarakat sekitar dalam kategori kosmetik perawatan alami tertentu. Nilai FL yang tinggi menunjukkan bahwa penggunaan suatu jenis tumbuhan untuk suatu kategori pemanfaatan tertentu telah menjadi sebuah kebiasaan atau tradisi di masyarakat setempat, sehingga informasi yang diberikan oleh informan seragama (Eni dkk, 2019).

Nilai FL terendah yang diperoleh yaitu $25 \%$ dimiliki oleh padi (Oryza sativa L.) pada kategori perawatan rambut. Nilai FL 25\% ini menunjukkan bahwa spesies tersebut kemungkinan bukan merupakan komponen utama dalam ramuan untuk kategori pemanfaatan tersebut, melainkan hanya sebagai bahan tambahan atau bahan opsional saja. Hal ini dapat menjadi suatu jawaban mengapa nilai ICS dan nilai FL untuk Oryza sativa L. tidak saling 
Author et al. (2020). Jurnal Biologi Tropis, 20 (2): $\mathrm{xx}-\mathrm{xx}$ DOI: http://dx.doi.org/xxxx

berkaitan, dimana pada perhitungan ICS spesies tersebut memiliki ranking tertinggi dari 27 spesies.

Tabel 5. Indeks FL tumbuhan kosmetik perawatan alami

\begin{tabular}{|c|c|c|c|}
\hline \multirow{2}{*}{ No } & \multicolumn{2}{|r|}{ Nama } & \multirow{2}{*}{$\% \mathbf{F L}$} \\
\hline & Indonesia & Spesies & \\
\hline \multicolumn{4}{|c|}{ Kategori wajah dan kulit } \\
\hline 1 & Adas & $\begin{array}{l}\text { Foeniculum vulgare } \\
\text { Mill }\end{array}$ & 100 \\
\hline 2 & Bayam pasir & $\begin{array}{l}\text { Amaranthus arenicola } \\
\text { LM. Johnst. }\end{array}$ & 100 \\
\hline 3 & Jahe & $\begin{array}{l}\text { Zingiber officinale } \\
\text { Roscoe }\end{array}$ & 40 \\
\hline 4 & Kayu manis & $\begin{array}{l}\text { Cinnamomum verum } \mathrm{J} . \\
\text { Presl }\end{array}$ & 100 \\
\hline 5 & Ketumbar & Coriandrum sativum $\mathrm{L}$. & 100 \\
\hline 6 & Kencur & Kaempferia galanga $\mathrm{L}$. & 100 \\
\hline 7 & Kunyit & Curcuma longa $\mathrm{L}$. & 83,33 \\
\hline 8 & Padi & Oryza sativa $\mathrm{L}$. & 75 \\
\hline 9 & Sidaguri & Sida rhombifolia $\mathrm{L}$. & 100 \\
\hline 10 & Turi & $\begin{array}{l}\text { Sesbania grandiflora } \\
\text { (L.) Pers }\end{array}$ & 100 \\
\hline 11 & Temulawak & $\begin{array}{l}\text { Curcuma zanthorrhiza } \\
\text { Roxb. }\end{array}$ & 100 \\
\hline 12 & Terulak & Ipomoea alba $\mathrm{L}$. & 100 \\
\hline 13 & Buah putat & $\begin{array}{l}\text { Barringtonia racemosa } \\
\text { (L.) Spreng }\end{array}$ & 100 \\
\hline 14 & $\begin{array}{l}\text { Kembang } \\
\text { sengeh }\end{array}$ & $\begin{array}{l}\text { Saponaria officinalis L. } \\
\text { bouncingbet }\end{array}$ & 100 \\
\hline \multicolumn{4}{|c|}{ Kategori rambut } \\
\hline 1 & Kelapa & Cocos nucifera $\mathrm{L}$. & 100 \\
\hline 2 & Kemiri & $\begin{array}{l}\text { Aleurites moluccanus } \\
\text { (L.) Willd }\end{array}$ & 100 \\
\hline 3 & Lidah buaya & Aloe vera (L.) Burm.f. & 100 \\
\hline 4 & Padi & Oryza sativa $\mathrm{L}$. & 25 \\
\hline 5 & Pisang & Musa & 100 \\
\hline 6 & $\begin{array}{l}\text { Daun tandan } \\
\text { lilin }\end{array}$ & $\begin{array}{l}\text { Ipomoea sepiaria } \\
\text { Koenig ex Roxb. }\end{array}$ & 100 \\
\hline \multicolumn{4}{|c|}{ Kategori gigi dan mulut } \\
\hline 1 & Pinang & Areca catechu $\mathrm{L}$. & 100 \\
\hline 2 & Sirih & Piper betle L. & 100 \\
\hline \multicolumn{4}{|c|}{ Kategori pasca melahirkan dan bayi } \\
\hline 1 & Aren & $\begin{array}{l}\text { Arenga } \\
\text { pinnata (Wurmb) Merr. }\end{array}$ & 100 \\
\hline 2 & Banten & $\begin{array}{l}\text { Lannea coromandelica } \\
\text { (Houtt.) Merr }\end{array}$ & 100 \\
\hline 3 & Cabe jawa & Piper retrofractum Vahl & 100 \\
\hline 4 & Cengkeh & $\begin{array}{l}\text { Syzygium aromaticum } \\
\text { (L.) Merr. \& LMPerry }\end{array}$ & 100 \\
\hline 5 & Jahe & $\begin{array}{l}\text { Zingiber officinale } \\
\text { Roscoe }\end{array}$ & 100 \\
\hline 6 & Jarak & Jatropha curcas L. & 100 \\
\hline 7 & Jeruk nipis & $\begin{array}{l}\text { Citrus aurantiifolia } \\
\text { (Christm.) Swingle }\end{array}$ & 100 \\
\hline 8 & Kayu manis & $\begin{array}{l}\text { Cinnamomum verum } \mathrm{J} . \\
\text { Presl }\end{array}$ & 100 \\
\hline 9 & Ketumbar & Coriandrum sativum $\mathrm{L}$. & 100 \\
\hline 10 & Kencur & Kaempferia galanga $\mathrm{L}$. & 100 \\
\hline
\end{tabular}

\begin{tabular}{lllc}
11 & Kunyit & Curcuma longa L. & 100 \\
12 & Padi & Oryza sativa L. & 50 \\
13 & Sidaguri & Sida rhombifolia L. & 100 \\
14 & Temulawak & $\begin{array}{l}\text { Curcuma zanthorrhiza } \\
\text { Roxb. }\end{array}$ & 100 \\
15 & $\begin{array}{l}\text { Kembang } \\
\text { sengeh }\end{array}$ & $\begin{array}{l}\text { Saponaria officinalis } \text { L. } \\
\text { bouncingbet }\end{array}$ & 100 \\
\hline
\end{tabular}

\section{Kesimpulan}

Berdasarkan hasil penelitian yang diperoleh dapat disimpulkan bahwa terdapat 13 ramuan kosmetik perawatan alami yang dimanfaatkan oleh masyarakat Batujai yang tergolong dalam kategori wajah dan kulit, gigi dan mulut, pasca melahirkan dan bayi, serta rambut. Tumbuhan yang dimanfaatkan sebagai kosmetik perawatan alami sebanyak 27 spesies tumbuhan dengan 18 famili. Nilai ICS tertinggi yaitu 42 terdapat pada tumbuhan padi (Oryza sativa L.) dan nilai ICS terendah yaitu 6 terdapat pada tumbuhan Amaranthus arenicola, Musa, Cocos nucifera L., Aleurites moluccanus, Aloe vera, Citrus xaurantiifolia, Syzygium aromaticum (L.) Merr., Piper retrofractum Vahl., Lannea coromandelica, Jatropha curcas L., Ipomoea alba L., Ipomoea sepiaria dan Barringtonia racemosa. Nilai FL tumbuhan kosmetik perawatan alami masyarakat desa Batujai berkisar antara $25 \%$ sampai $100 \%$.

\section{Ucapan Terima Kasih}

Penulis mengucapkan banyak terimakasih kepada pejabat, tokoh masyarakat dan masyarakat desa Batujai Kecamatan Praya Barat Lombok Tengah dalam partisipasinya.

\section{Referensi}

Agero, A.L.C. dan Vermến M. V-R. 2004. A Randomized Double-Blind Controlled Trial Comparing Extra Virgin Coconut Oil with Mineral Oil as a Moisturizer for Mild to Moderate Xerosis. Dermatitis. 15(3), 109-16. DOI: 10.2310/6620.2004.04006.

Andarina, R. dan Djauhari, T. 2017. Antioksidan dalam Dermatologi. Jurnal Kimia dan Kemasan (JKK). 4(1), 39-48. https://ejournal.unsri.ac.id/index.php/jkk/artic le/view/6094/3284. 
Batoro, J. (2015). Pengelolaan Lingkungan Dengan Pendekatan Etnobiologi-Etnobotani. Malang: UB Press. ISBN: 978-602-203-781-1.

Chen, Q. (2009). Evaluate the Effectiveness of the Natural Cosmetic Product Compared to Chemical-Based Products. International Journal of Chemistry. 1 (2), 57-59. DOI: 10.5539/ijc.v1n2p57.

De Almeida, C.D.F.C.B.R., Ramos, M.A., Silva, R.R.V., De Melo, J.G., Medeiros, M.F.T., Araujo, T.A.D.S., De Almeida, A.L.S., De Amorim, E.L.C., Alves, R.R.D.N., dan De Albuquerque, U.P. (2012). Intracultural Variation in the Knowledge of Medicinal Plants in an Urban-Rural Community in the Atlantic Forest from Northeastern Brazil. Evidence-Based Complementary Alternatif Medicine. 2012: 1-15. DOI: $10.1155 / 2012 / 679373$.

Eni, N.N.S., Sukenti, K., Muspiah, A. dan Rohyani, I.S. (2019). Studi Etnobotani Tumbuhan Obat Masyarakat Komunitas Hindu Desa Jagaraga, Kabupaten Lombok Barat, Nusa Tenggara Barat. Biotropika: Journal of Troical Biology. 7(3): 121-128. DOI: 10.21776/ub.biotropika.2019.007.03.5.

Friedman, J., Yaniv, Z., Dafni, A. \& Palewitch, D. (1986). A Preliminary Classification of The Healing Potential of Medicinal Plants, Based on A Rational Analysis of An Ethnoopharmacological Field Survey Among Bedouins in The Negev Desert, Israel. Journal of Ethnopharmacology. 16: 275-287. DOI: https://doi.org/10.1016/0378-8741(86)900942 .

Hoofman, B. \& Gallaher, T.J. (2007). Importance Indices in Ethnobotany. Ethnobotany Research \& Application. 5: 201-218. DOI: 10.1234/era.v5i0.130.

Irawan, Y.R., Fitmawati \& Herman (2013). Pengetahuan Tanaman Obat Dusun Sakai Desa Sebangar Duri Tiga Belas \& Desa Kesumbo Ampai Duri Kabupaten Bengkalis. Jurnal Biosaintifika. 5(1): 191-208. DOI: 20.15294/biosaintifika.v5i1.2571.
ITA (2018). Brief On Indonesian Cosmetics Industry, Import Regulations, Problems, Procedures, Registration, Import Duties. Jakarta: Italian Trade Agency.

Jannah, H. \& Ridwan. (2013). Pengobatan Tradisional Suku Sasak Berbasis Ilmiah di Kabupaten Lombok Barat. Jurnal Ilmiah Biologi “Bioscientist”.1 (2): 116-125. DOI: https://doi.org/10.33394/bjib.v1i2.790.

Joshi, L.S. \& Pawar, H.A. (2015). Herbal Cosmetics and Cosmeceuticals: An Overview. Natural Products Chemistry \& Research. 3 (2): 1-8. DOI: 10.4172/2329-6836.1000170.

Julie, J. \& Ernes, T.J. (2012). Evaluation of Antioxidant Potensial of Rhizome Extyracts of Two Species of Alpinia Roxb. (Zingiberaceae). International Research Journal of Pharmacy. 3(4), 402-404. https://www.researchgate.net/publication/331 593072 EVALUATION OF ANTIOXIDA NT_POTENTIAL_OF_RHIZOME_EXTRA CTS_OF_TWO_SPECIES_OF_ALPINIA_R OXB_ZINGIBERACEAE.

Khan, I. Abdelsalam, N.M., Fouad, H., Tariq, A., Ullah, R., \& Adnan, M. (2014). Application of Ethnobotanical Indices on the Use of Traditional Medicines Against Common Diseases. Evidence-Based Complementary Alternatif Medicine. 2014: 1-24. DOI: http;//dx.doi.org/10.1155/2014/635371.

Na'imah, J. (2018). Optimasi Masker Beras Untuk Wajah. Jurnal Ilmu Kesehatan. 4(1): 1-10. http://eprints.umg.ac.id/id/eprint/4110.

Novianti (2014). Kajian Etnofarmakognosi dan Etnofarmakologi Penggunaan Tumbuhan Obat di Desa Cisangkal Kecamatan Cihurip Kabupaten Garut Tahun 2014. Farmako Bahari. 5(2): 5-23. http://journal.uta45jakarta.ac.id/index.php/I NRPJ/article/view/779.

Nurdiani, N. (2014). Teknik Sampling Snowball Dalam Penelitian Lapangan. ComTech. 5(2), 
1110-1118. DOI:

https://doi.org/10.21512/comtech.v5i2.2427.

Ramadhania, Z.M., Tjitraresmi, A. \& Nuwarda, R.F. (2018). Edukasi Pemanfaatan Herbal Sebagai Bahan Kosmetik Alami di Kecamatan Ciwaringin Kabupaten Cirebon. Jurnal Aplikasi Ipteks untuk Masyarakat. 7(3):189192.

DOI:

https://doi.org/10.24198/dharmakarya.v7i3.1

9497.

Shobana, S. \& Naide, K.A. (2000). Antioxidant Activity of Selected Indian Spices. Porstaglandins, Leukotrienes and Essential Fatty Acids (PLEFA). 62(2), 107-110. DOI: https://doi.org/10.1054/plef.1999.0128.

Simorangkir, M., Subakti, R., Barus, T. \& Simanjuntak, P. (2017). Analisis Fitokimia Metabolit Sekunder Ekstrak Daun dan Buah Solanum blumei Nees ex Blume lokal. Jurnal Pendidikan Kimia. 9(1): 244-248. DOI: 10.24114/jpkim.v9i1.6186.

Turner, N.J. (1988). The Importance of a Rose: Evaluating The Cultural Significance of Plants in Thompson and Lillooet Interior Salish. Journal of American Anthropologist. $90 \quad$ (2): $\quad 272-290 . \quad$ DOI: 10.1525/aa.1988.90.2.02a00020.

Ugula, I. (2012). Fidelity Level and Knowledge of Medicinal Plants Used to Make Therapeutic Turkish Baths. Ethno Med. 6(1): 1-9. DOI:https://doi.org/10.1080/09735070.2012. 11886413.

Wahidah, B.F. (2013). Potensi Tumbuhan Obat di Area Kampus II UIN Alaudin Samata Gowa. Jurnal Teknosains. 7 (1): 111-119. DOI: https://doi.org/10.24252/teknosains.v7i1.78.

Wathoni, N., Ani H., Nia Y., \& Retno H. (2018). A Review On Herbal Cosmetics in Indonesia. International Journal of Apllied Pharmaceutics. 10 (5), 13-16. DOI: 10.22159/ijap.2018v10i5.28102.

Wiharsari, J.C. 2019. Konsep Kecantikan dan Pemanfaatan Produk Kosmetik Wajah Pada
Mahasiswa Surabaya. Surabaya: Universitas Airlangga.http://journal.unair.ac.id/AUN@k onsep-kecantikan-dan-pemanfaatan-produkkosmetik-wajah-pada-mahasiswi-surabayaarticle-12584-media-134-category-8.html 